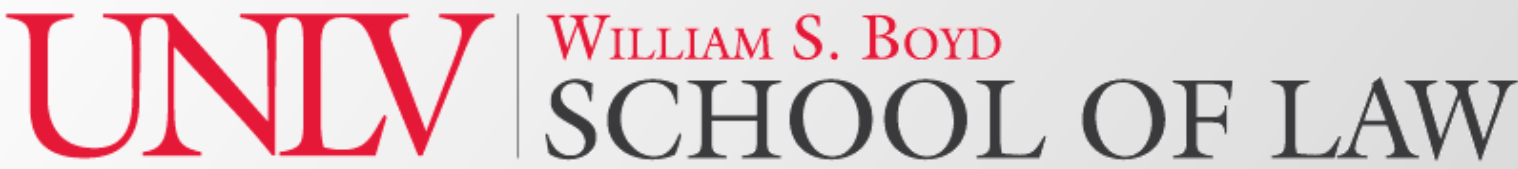

\section{Extraterritorial Enforcement of National Laws in Connection with Online Commercial Activity}

\author{
Marketa Trimble \\ Associate Professor of Law \\ William S. Boyd School of Law
}

Internet Law Works-in-Progress Santa Clara Law March 7, 2015 
- National laws on the internet

○ Transnational forces forming national laws

- Enforcement not limited to state enforcement power

- Alternative enforcement in the shadow of state enforcement

○ Extraterritorial enforcement

- Remote and decentralized activity on the internet

- Impact of uncertain enforcement on substantive law debates 
- Transnational commercial activity

- All aspects of online commerce;

not limited to "commercial law" or EU E-Commerce Directive

- No internet infrastructure governance issues

- International, not inter-state commercial activity

- Limits on the ubiquitousness

- Geoblocking

- Other targeting

- Other traditional market-partitioning tools

- Lack of uniformity

- Tangible $v$. intangible goods 


\section{Prescriptive and Adjudicatory Perspectives}

- Point-of-source v. point-of-consumption principle

○ Point-of-source principle

- $\quad$ EU E-Commerce Directive

○ Point-of-consumption principle

- U.K. Gambling (Licensing and Advertising) Act 2014

- Attractiveness of the point-of-source principle

- Issues of proper localization

- Enforcement issues

- Benefits of the point-of-consumption principle

- Substantive content as a problematic guideline to the selection of the principle 


\section{A Country's Enforcement Power}

○ Jurisdiction and enforcement power over the defendant

- Territorially-limited enforcement

- Secondary liability and intermediaries

○ Border measures

\section{Enforcement Assistance from Other Countries}

$\odot$ Judgments by courts of general v. specific jurisdiction

- Limitations on application of foreign law and enforcement of foreign judgments

Territorial Scope of Injunctions on the Internet 


\section{Supranational Limitations on Extraterritorial Enforcement}

- Free movement of goods and services (EU, EEA)

- No barriers to trade (WTO)

๑ Exceptions

\section{Possibilities for Improvement}

- Rogue countries

- Alternative enforcement problems

- Location of servers; intermediaries

- Enforcement of public law v. private law

○ Industry actions 


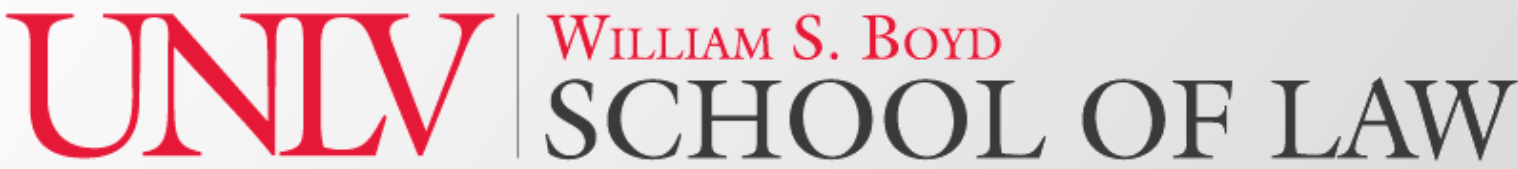

\section{Extraterritorial Enforcement of National Laws in Connection with Online Commercial Activity}

\author{
Marketa Trimble \\ Associate Professor of Law \\ William S. Boyd School of Law
}

Internet Law Works-in-Progress Santa Clara Law March 7, 2015 